\title{
Purification and Identification of Novel Xanthine Oxidase Inhibitory Peptides Derived from Round Scad (Decapterus maruadsi) Protein Hydrolysates
}

\author{
Xiao Hu ${ }^{1,2} \oplus$, Ya Zhou ${ }^{1,3}$, Shaobo Zhou ${ }^{4}\left(\right.$ ) , Shengjun Chen ${ }^{1}$, Yanyan Wu ${ }^{1,5}$, Laihao $\mathrm{Li}^{1,2}$ and Xianqing Yang ${ }^{1, *}$ \\ 1 Key Laboratory of Aquatic Product Processing, Ministry of Agriculture and Rural, South China Sea Fisheries \\ Research Institute, Chinese Academy of Fishery Sciences, Guangzhou 510300, China; \\ huxiao@scsfri.ac.cn (X.H.); zhouya_zy@163.com (Y.Z.); chenshengjun@scsfri.ac.cn (S.C.); \\ wyy@scsfri.ac.cn (Y.W.); lilaihao@scsfri.ac.cn (L.L.) \\ 2 Co-Innovation Center of Jiangsu Marine Bio-Industry Technology, Jiangsu Ocean University, \\ Lianyungang 222005, China \\ 3 College of Food Science \& Technology, Shanghai Ocean University, Shanghai 201306, China \\ 4 School of Life Sciences, Institute of Biomedical and Environmental Science and Technology, \\ University of Bedfordshire, Luton LU1 3JU, UK; shaobo.zhou@beds.ac.uk \\ 5 Collaborative Innovation Center of Provincial and Ministerial Co-Construction for Marine Food \\ Deep Processing, Dalian 116034, China \\ * Correspondence: yangxq@scsfri.ac.cn
}

\section{check for} updates

Citation: Hu, X.; Zhou, Y.; Zhou, S.; Chen, S.; Wu, Y.; Li, L.; Yang, X. Purification and Identification of Novel Xanthine Oxidase Inhibitory Peptides Derived from Round Scad (Decapterus maruadsi) Protein Hydrolysates. Mar. Drugs 2021, 19, 538. https://doi.org/10.3390/ md19100538

Academic Editors: Hideki Kishimura and Yuya Kumagai

Received: 23 August 2021

Accepted: 21 September 2021

Published: 24 September 2021

Publisher's Note: MDPI stays neutral with regard to jurisdictional claims in published maps and institutional affiliations.

Copyright: (c) 2021 by the authors. Licensee MDPI, Basel, Switzerland. This article is an open access article distributed under the terms and conditions of the Creative Commons Attribution (CC BY) license (https:// creativecommons.org/licenses/by/ $4.0 /)$.
Abstract: The objective of the present study was to investigate the xanthine oxidase $(\mathrm{XO})$ inhibitory effects of peptides purified and identified from round scad (Decapterus maruadsi) hydrolysates (RSHs). In this study, RSHs were obtained by using three proteases (neutrase, protamex and alcalase). Among them, the RSHs of 6-h hydrolysis by neutrase displayed the strongest XO inhibitory activity and had an abundance of small peptides $(<500 \mathrm{Da})$. Four novel peptides were purified by immobilized metal affinity chromatography and identified by nano-high-performance liquid chromatography mass/mass spectrometry. Their amino acid sequences were KGFP (447.53 Da), FPSV (448.51 Da), FPFP (506.59 Da) and WPDGR (629.66 Da), respectively. Then the peptides were synthesized to evaluate their XO inhibitory activity. The results indicated that the peptides of both FPSV $(5 \mathrm{mM})$ and FPFP ( $5 \mathrm{mM}$ ) exhibited higher XO inhibitory activity ( $22.61 \pm 1.81 \%$ and $20.09 \pm 2.41 \%$ respectively). Fluorescence spectra assay demonstrated that the fluorescence quenching mechanism of $\mathrm{XO}$ by these inhibitors (FPSV and FPFP) was a static quenching procedure. The study of inhibition kinetics suggested that the inhibition of both FPSV and FPFP was reversible, and the type of their inhibition was a mixed one. Molecular docking revealed the importance of $\pi-\pi$ stacking between Phe residue (contained in peptides) and $\mathrm{Phe}^{914}$ (contained in the $\mathrm{XO}$ ) in the XO inhibitory activity of the peptides.

Keywords: round scad (Decapterus maruadsi); hydrolysis; peptides; xanthine oxidase inhibitory; purification; identification

\section{Introduction}

Hyperuricemia is currently recognized as the fourth highest-risk chronic disease after hyperglycemia, hypertension, and hyperlipidemia, which could cause complications such as gout, hypertension and diabetes disease [1]. It is a metabolic disease mainly caused by the production of excess uric acid or uric acid excretion disorder in the body [2]. Excessive uric acid may lead to the sedimentation of urate crystals in joints and gout. Studies had demonstrated that gout is associated with hypertension, atherosclerosis, insulin resistance, cardiovascular diseases and renal diseases [3]. Xanthine oxidase (XO, EC 1.17.3.2) is a key enzyme involved in purine metabolism and biosynthesis of uric acid [4]. $\mathrm{XO}$ is a homodimer with a molecular mass of approximately $290 \mathrm{kDa}$ [5]. Each monomer of XO contains one $\mathrm{N}$-terminal domain $(20 \mathrm{kDa})$ including two iron-sulfur centers (Fe/S I and 
$\mathrm{Fe} / \mathrm{S} \mathrm{II})$, one central flavin adenine dinucleotide domain (40 kDa), and one C-terminal molybdopterin-binding domain $(85 \mathrm{kDa})$ with the four redox centers aligned in an almost linear fashion [6]. Catalytic reaction occurs at molybdopterin-binding domain [7]. Due to the fact that $\mathrm{XO}$ could catalyze the oxidation of hypoxanthine to xanthine and xanthine to uric acid, the inhibition of $\mathrm{XO}$ is a main approach for decreasing the production of uric acid and alleviating the progress of hyperuricemia. The general treatment strategy for hyperuricemia was using traditional drugs such as allopurinol and febuxostat. This could effectively inhibit $\mathrm{XO}$ activity and alleviate pain caused by gout in the short term, but most of them were found in clinical trials to present adverse side effects $[8,9]$. Thus, it is critical to develop a natural and efficient $\mathrm{XO}$ inhibitory agent. In recent years, the focus of the researches has switched to discovering food-derived bioactive peptides with high $\mathrm{XO}$ inhibitory properties and minimal side effects. For example, protein-based peptides such as milk-derived peptide (YLDNY) and walnut protein-derived peptides (WPPKN and ADIYTE) had shown XO inhibitory activity $[10,11]$. Moreover, several studies had found that marine fish (such as bonito, tuna and shark) protein hydrolysates displayed high XO inhibitory activity [12-17].

Round scad (Decapterus maruadsi) is a kind of marine fish belonging to the family of mackerel, which is widely found in distributed warm, nearshore waters of China [18]. The current utilization of the round scad is limited due to its dark color, small size, susceptibility to oxidation, and poor flavor [19]. Therefore, this fish is usually considered as a bycatch species and processed into low-value products such as fish meal, fertilizer or even discarded, entailing considerable waste [20]. It is urgently needed to develop higher value-added products to increase the utilization and economic value of the round scad. Recently, the deep processing of round scad has attracted increasing attentions, and some bioactive peptides (antioxidant peptides and memory improving peptides) have been obtained from round scad protein [20-23]. However, little information is available on the $\mathrm{XO}$ inhibitory activity of the peptides derived from round scad hydrolysates (RSHs).

In the present study, the $\mathrm{XO}$ inhibitory activity of RSHs prepared by different proteases was investigated. The $\mathrm{XO}$ inhibitory peptides in the hydrolysates were further isolated and identified by immobilized metal affinity chromatography (IMAC) and nanohigh-performance liquid chromatography mass/mass spectrometry (nano-HPLC-MS/MS). Finally, the identified peptides were synthesized for determining their XO inhibitory activity. The inhibition kinetics study and molecular docking simulation were used for further exploring potential inhibitory mechanism of the $\mathrm{XO}$ inhibitory peptides.

\section{Results and Discussion}

\subsection{XO Inhibitory Activity of RSHs}

Since different enzymes have specific cleavage sites on polypeptide chains, three proteases (neutrase, protamex and alcalase) were employed to hydrolyze the round scad proteins. As shown in Figure 1, the XO inhibitory activity and the degree of hydrolysis of the RSHs (obtained by using neutrase, protamex and alcalase) were measured at various hydrolysis times. The hydrolysates obtained by neutrase showed the potent $\mathrm{XO}$ inhibitory activity. The $\mathrm{XO}$ inhibitory activity of the neutrase hydrolysates was dramatically increased with the increase of hydrolysis time $(1-6 \mathrm{~h})$. At $6 \mathrm{~h}$, the $\mathrm{XO}$ inhibitory activity reached a maximum value of $62.79 \pm 1.41 \%(15 \mathrm{mg} / \mathrm{mL})$, and the degree of hydrolysis was $15.30 \pm 0.16 \%$. Subsequently, the XO inhibitory activity showed a small decrease when the hydrolysis time was over $6 \mathrm{~h}$, which indicated that excessive hydrolysis was not conducive to the hydrolysate to exhibit high $\mathrm{XO}$ inhibitory activity. This result showed that both the enzyme type and the time of hydrolysis could impact XO inhibitory activity of RSHs. Li et al. (2018) reported that bonito hydrolysates produced using papain exhibited the highest XO inhibitory ability, compared to walnut hydrolysates and soybean hydrolysates [12]. He et al. (2019) investigated that the tuna protein hydrolysates produced by using alcalase showed XO inhibitory activity [13]. 


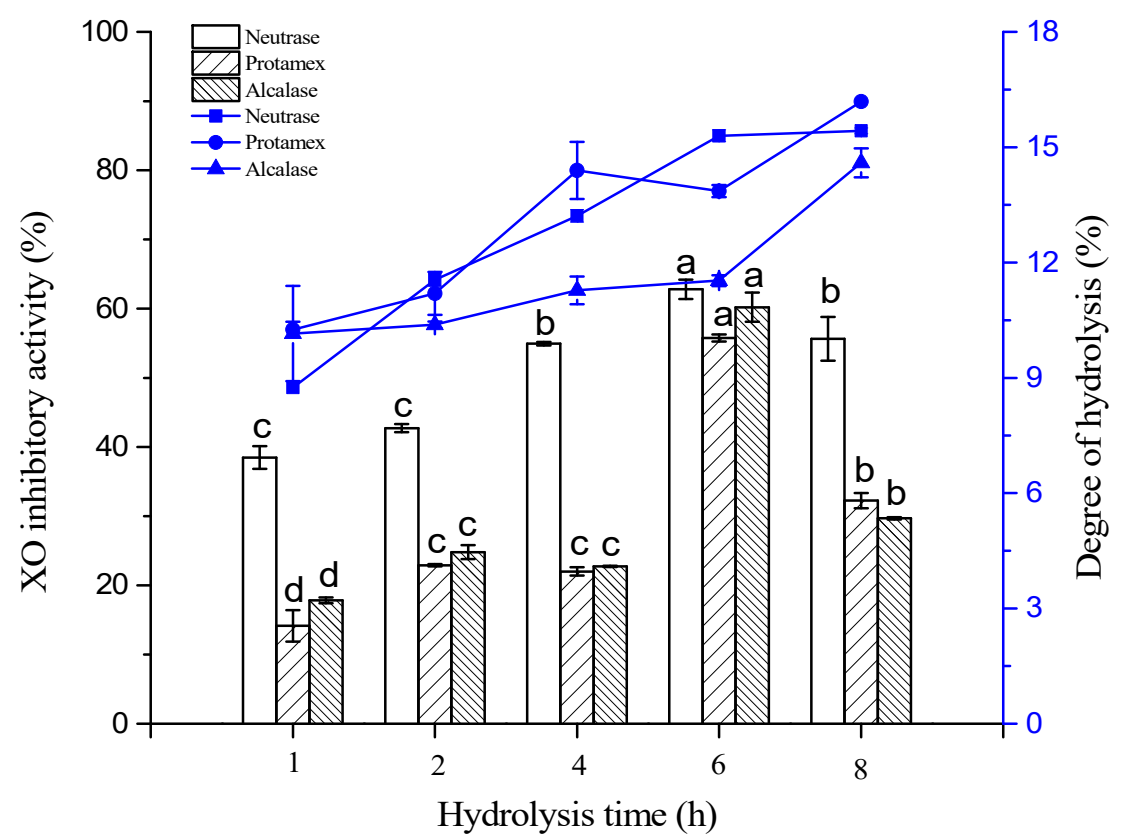

Figure 1. XO inhibitory activity and the degree of hydrolysis of the RSHs obtained by hydrolysis with different proteases. Different letter of ' $\mathrm{a}-\mathrm{c}$ ' on the top of same pattern column represents significant difference $(p<0.05)$ in the XO inhibitory activity of RSHs obtained by same protease at different hydrolysis time. For example, the first column represents the XO inhibitory activity of RSHs obtained by neutrase from hydrolysis among 1 to $8 \mathrm{~h}$. There is a significant difference between $6 \mathrm{~h}$ (labelled with ' $a$ ') to both 4 and $8 \mathrm{~h}$ (both labelled with ' $\mathrm{b}$ ' which means no significant difference between 4 and $8 \mathrm{~h}$ ) or to both 1 and $2 \mathrm{~h}$ (both labelled with ' $\mathrm{c}$ '). Same rule also used for 'a-d' for the RSHs obtained by protamex or by alcalase (middle or last column of different hydrolysis time).

\subsection{Molecular Weight Distribution of RSHs}

It has been reported that peptides with low MW usually could be more easily absorbed and strongly influenced their biological activities [24]. In order to investigate the relationship between MW distribution and XO inhibitory activity, the MW distributions of RSHs obtained with neutrase are shown in Figure 2A. The relative content of fractions with different MW in RSHs was calculated by the percentage of the integral area of the curve (Figure 2B). With the extension of the hydrolysis time, the content of the fraction with a MW below 500 Da significantly increased from $54.60 \%$ to $76.33 \%$, while the content of the fraction with a MW range of 1000-3000 Da significantly decreased from $15.53 \%$ to $5.00 \%$. In the previous section, we found that as the hydrolysis time was increased from $2-6 \mathrm{~h}$, the $\mathrm{XO}$ inhibitory activity of the hydrolysates was dramatically increased, but there was a decrease occurred when the hydrolysis time was over $6 \mathrm{~h}$ (Figure 1). This was suggested that low MW (not too small MW) peptides were likely the important contributors of the significant XO inhibitory activity of RSHs. Currently, many low MW peptides with XO inhibitory activity have been identified, such as WML (448.21 Da), PGACSN (547.30 Da), WPPKN (640.74 Da) and ADIYTE (710.73 Da) [11,12]. Therefore, the RSHs (6 h hydrolysates obtained by neutrase) were selected for further separation and purification. 
(A)

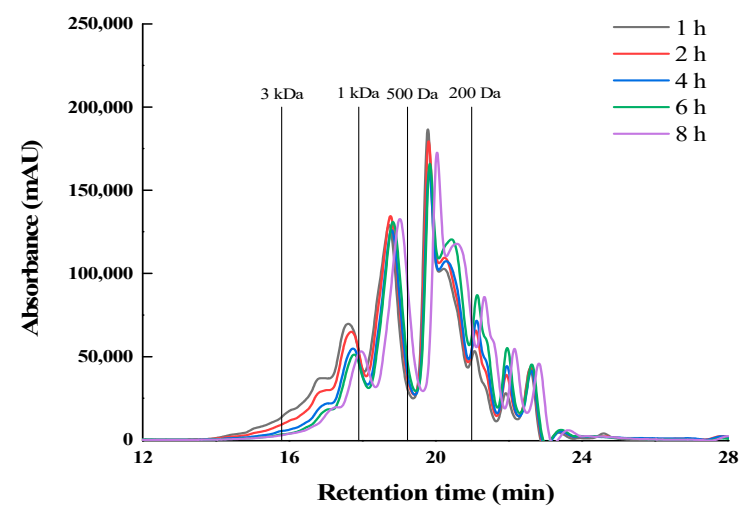

(B)

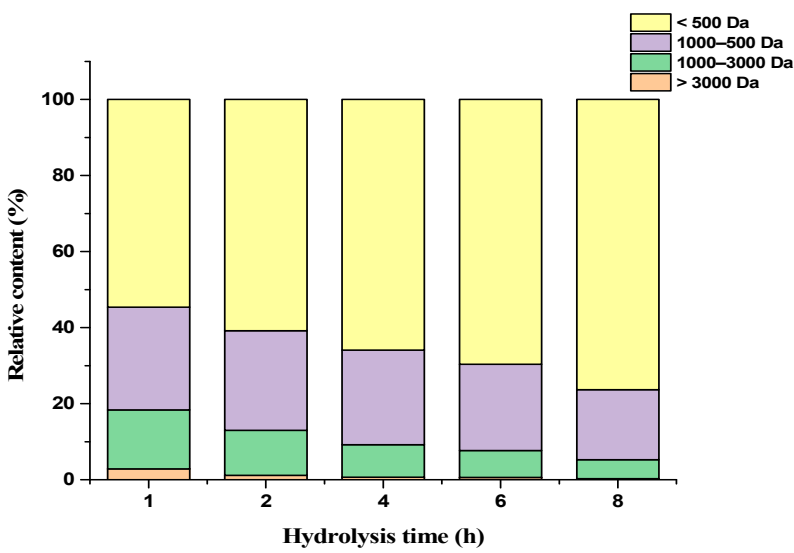

Figure 2. Molecular weight distribution (A) of RSHs obtained with neutrase and the relative content (B) of fractions with different molecular weight in RSHs.

\subsection{Purification and Identification of XO Inhibitory Peptides}

Immobilized metal affinity chromatography (IMAC) was widely used in the separation and purification of metal chelating peptides due to its specific metal biosorption capacity [25]. It has been reported that IMAC can be used as an effective approach to separate low MW peptides because it can reduce the adsorption interference of large proteins [26]. RSHs with the highest XO inhibitory activity (6 h hydrolysates obtained by neutrase) were further purified via IMAC. As shown in Figure 3, two fractions (F1 and F2) were separated from the RSHs. The fraction F2 exhibited higher XO inhibitory activity $\left(\mathrm{IC}_{50}=8.03 \pm 0.05 \mathrm{mg} / \mathrm{mL}\right)$ than that of the fraction $\mathrm{F} 1\left(\mathrm{IC}_{50}=9.57 \pm 0.23 \mathrm{mg} / \mathrm{mL}\right)$. The amino acid sequences of the XO inhibitory peptides in the fraction F2 were further determined by nano-HPLC-MS/MS.

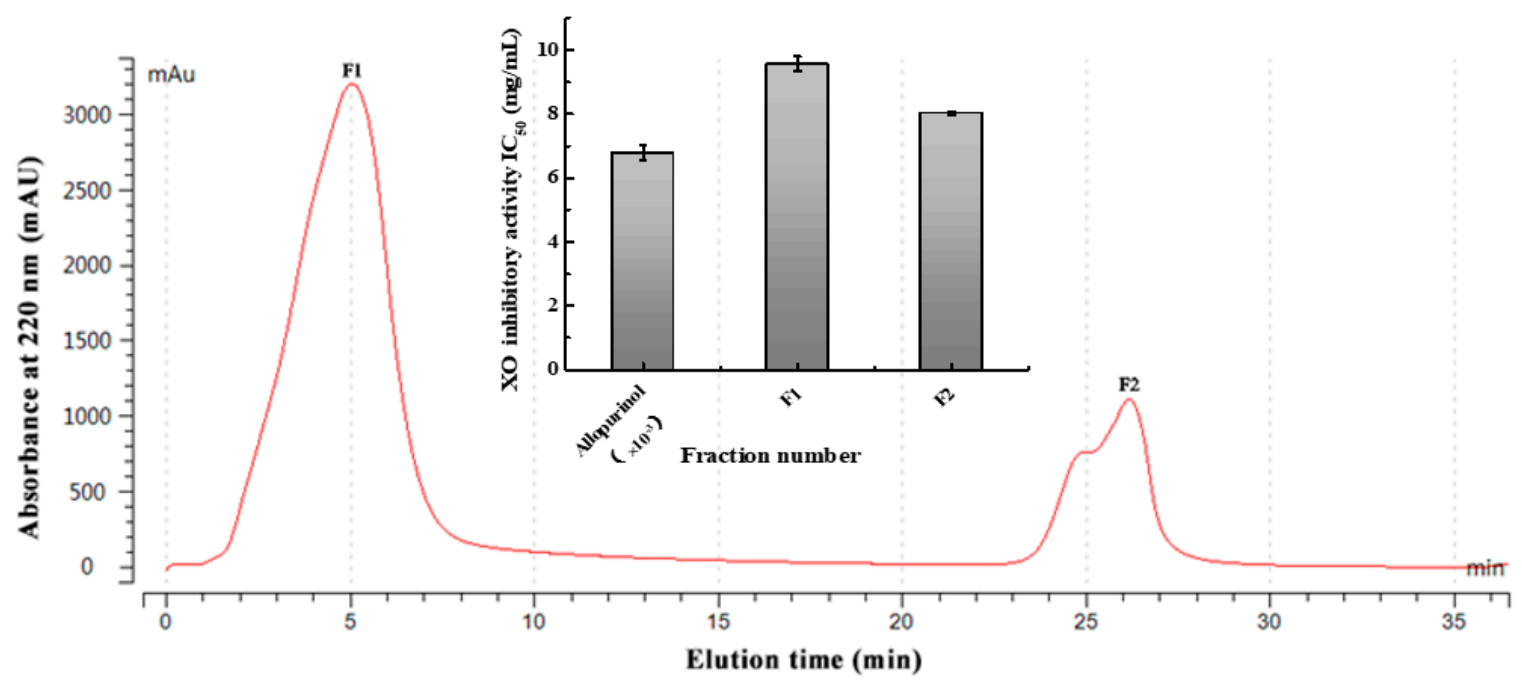

Figure 3. Separation of RSHs by IMAC and the XO inhibitory activity of the peptide fractions.

As shown in Figure 4, four XO inhibitory peptides were identified as KGFP (447.53 Da), FPSV (448.51 Da), FPFP (506.59 Da) and WPDGR (629.66 Da). It was found that the identified peptides contained at least one aromatic amino acid, such as F (Phe) and W (Trp). Subsequently, according to the amino acid sequences, the four identified peptides were chemically synthesized for evaluating its XO inhibitory activity. The XO inhibitory activity of the peptides are presented in Table 1 . At the same concentration $(5 \mathrm{mM})$, of all identified peptides, tetrapeptide FPSV had the highest XO inhibitory capacity $(22.61 \pm 1.81 \%)$, followed by FPFP $(20.09 \pm 2.41 \%)$, WPDGR $(16.21 \pm 0.78 \%)$ and KGFP $(5.43 \pm 0.20 \%)$. The XO inhibitory 
capacity of FPSV $(22.61 \pm 1.81 \%, 2.24 \mathrm{mg} / \mathrm{mL})$ or FPFP $(20.09 \pm 2.41 \%, 2.53 \mathrm{mg} / \mathrm{mL})$ was much higher than that of the isolated fraction F2 $(14.14 \pm 0.45 \%, 2.50 \mathrm{mg} / \mathrm{mL})$. All identified peptides were low MW oligopeptides ( $<650 \mathrm{Da})$. The low MW peptides seem to exhibit higher $\mathrm{XO}$ inhibitory activity and usually could be more easily absorbed than the high MW peptides [11]. Previously, it has been reported that Phe/Trp-containing peptides can be used as good XO inhibitors $[10,13,27,28]$. Interestingly, the peptides with higher XO inhibitory activity (FPSV and FPFP) contained both Phe and Pro residues. The XO inhibitory activity of peptides seems to be not as strong as some traditional drugs (such as allopurinol, $\mathrm{IC}_{50}=6.79 \pm 0.25 \mu \mathrm{g} / \mathrm{mL}$ or $0.0499 \pm 0.0013 \mathrm{mM}$ in Figure 3), but as natural agents derived from food protein, peptides have less side effects on human health.

(A)

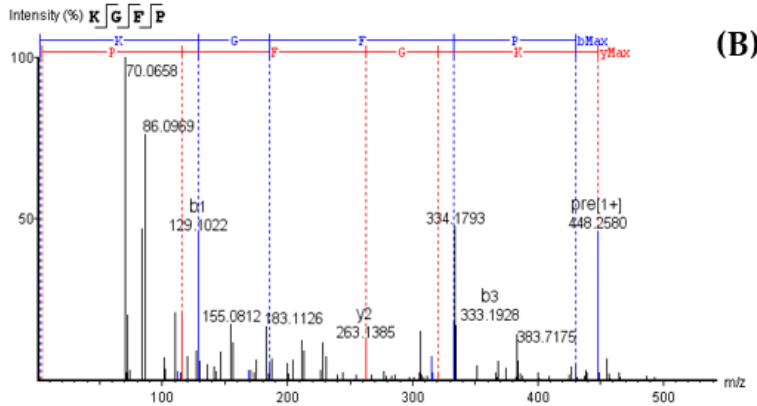

(C)

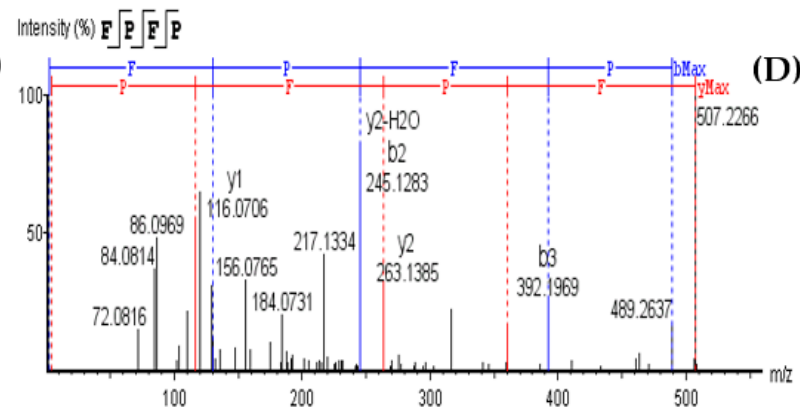

Intensity (x) $\mathbf{E} \sqrt{\mathbf{P}} \sqrt{\mathrm{s}} \sqrt{\mathrm{v}}$

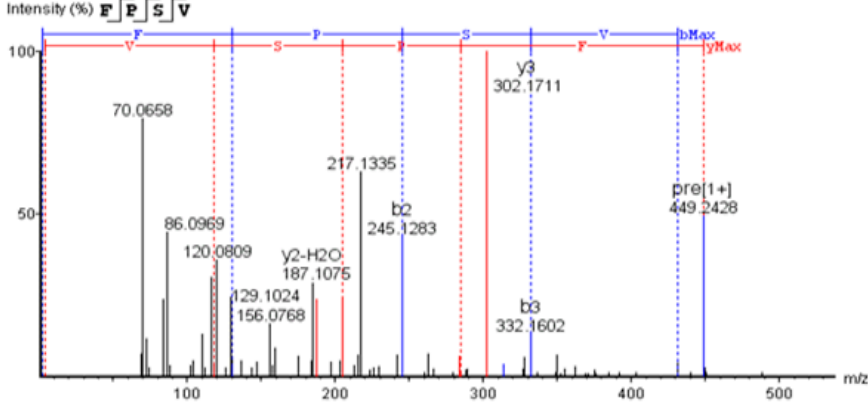

Intensity(x) $\mathrm{W} \widetilde{\mathrm{P}} \widetilde{\mathrm{D}} \widetilde{G} \widehat{\mathbb{R}}$

Figure 4. Identification of four XO inhibitory peptides in F2 by nano-HPLC-MS/MS, and the MS/MS spectra of KGFP (A), FPSV (B), FPFP (C) and WPDGR (D). The y1-4 and b1-3 are the y-type and b-type fragment ions in the MS/MS spectra.

Table 1. XO inhibitory activity of the identified peptides at the concentration of $5 \mathrm{mM}$.

\begin{tabular}{|c|c|c|c|}
\hline Peptides & MW (Da) & Structure Formula & XO Inhibitory Activity (\%) \\
\hline KGFP & 447.53 & & $5.43 \pm 0.20^{c}$ \\
\hline FPS V & 448.51 & & $22.61 \pm 1.81^{a}$ \\
\hline FPFP & 506.59 & & $20.09 \pm 2.41^{a}$ \\
\hline WPDGR & 629.66 & & $16.21 \pm 0.78^{b}$ \\
\hline
\end{tabular}

Values within the same column followed by the same letter are not significantly different $(p>0.05)$. 


\subsection{Fluorescence Quenching Studies of XO by FPSV and FPFP}

Fluorescence chromatographic analysis was used to further explore the binding mechanism between the peptides and $\mathrm{XO}$. There are three types of intrinsic fluorophores in XO, including Trp, Tyr and Phe. As Phe has a low fluorescence quantum yield and the fluorescence of Tyr is almost completely quenched near an amino group, a carboxyl group or a Trp residue, the intrinsic fluorescence intensity of $\mathrm{XO}$ is mainly attributed to Trp residues and slightly attributed to Tyr residues [7]. The fluorescence spectra of $\mathrm{XO}$ in the absence and presence of FPSV and FPFP under the excitation at $280 \mathrm{~nm}$ are shown in Figure 5. It was found that XO had two strong fluorescence emissions at $336 \mathrm{~nm}$ and $404 \mathrm{~nm}$ wavelengths. Since FPSV and FPFP had no Trp/Tyr residue, they almost had no intrinsic fluorescence under the experimental conditions. With increasing concentration of peptides FPSV (Figure 5A) and FPFP (Figure 5B), the intensity of the peak at $336 \mathrm{~nm}$ and $404 \mathrm{~nm}$ decreased but without obvious shift. This phenomenon indicated that peptides FPSV and FPFP could directly interact with $\mathrm{XO}$ and quench its inherent fluorescence.

(A)

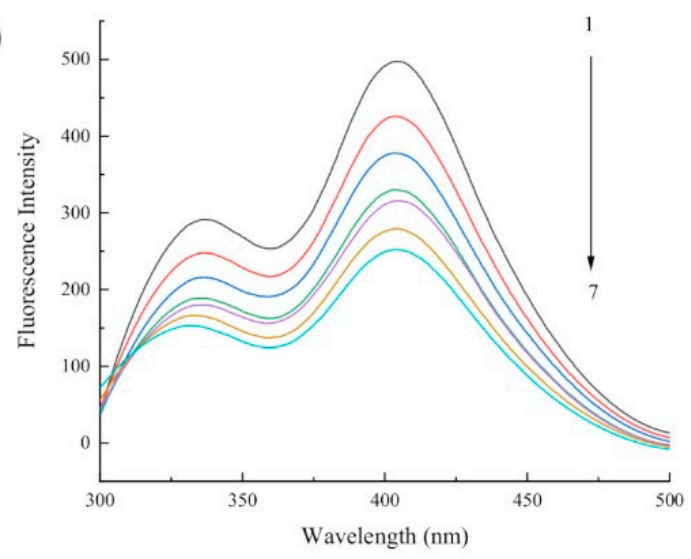

(B)

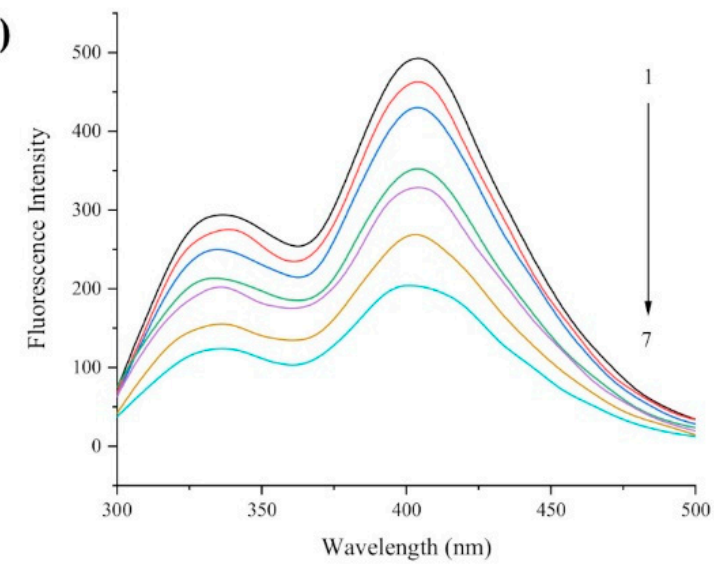

(C)

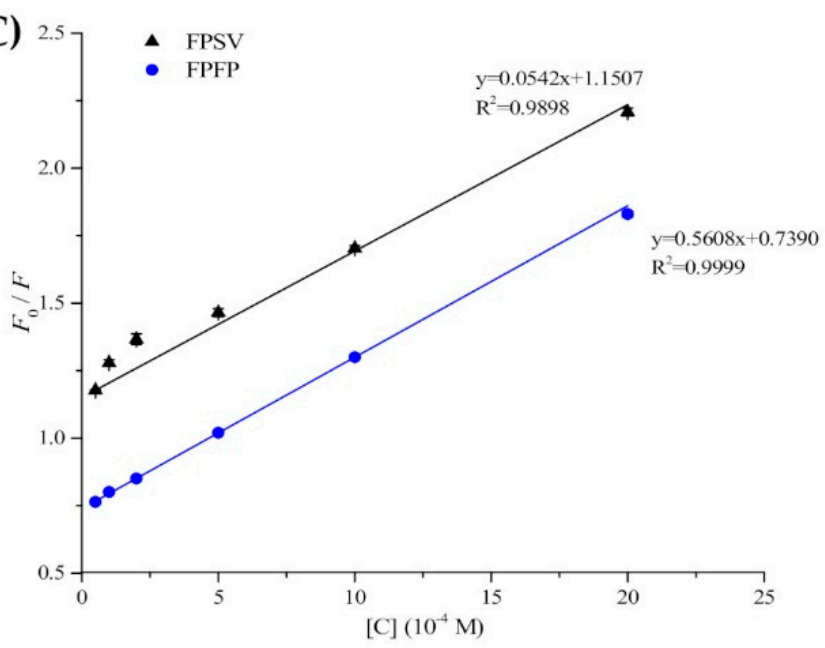

Figure 5. Fluorescence spectra of XO in the presence of FPSV (A) and FPFP (B) at different peptide concentrations (0, 0.5, 1.0, 2.0, 5.0, 10.0 and $20.0 \times 10^{-4} \mathrm{M}$ for curves $1 \rightarrow 7$, respectively) and the Stern-Volmer plots for the fluorescence quenching of XO by FPSV and FPFP (C).

The Stern-Volmer plots of FPSV and FPFP are shown in Figure 5C, and the calculated quenching constants $\mathrm{K}_{\mathrm{sv}}$ and $\mathrm{K}_{\mathrm{q}}$ at their corresponding temperatures are shown in Table 2. The calculated $\mathrm{K}_{\mathrm{sv}}$ and $\mathrm{K}_{\mathrm{q}}$ values of FPSV were $0.0542 \times 10^{4} \mathrm{M}^{-1}$ and $0.0542 \times 10^{12} \mathrm{M}^{-1} \mathrm{~s}^{-1}$, respectively. For the peptide FPFP, the $\mathrm{K}_{\mathrm{sv}}$ and $\mathrm{K}_{\mathrm{q}}$ values were calculated to be $0.5608 \times 10^{4} \mathrm{M}^{-1}$ and $0.5608 \times 10^{12} \mathrm{M}^{-1} \mathrm{~s}^{-1}$, respectively. The values of $\mathrm{K}_{\mathrm{q}}$ were markedly larger than the threshold of scattering collisional quenching constant 
$\left(2.0 \times 10^{-10} \mathrm{M}^{-1} \mathrm{~s}^{-1}\right)$ for a biomolecule [29]. This result suggested that the fluorescence quenching mechanism of XO by FPSV and FPFP might be a static rather than dynamic quenching procedure [30].

Table 2. Stern-Volmer quenching constants for the interaction of FPSV and FPFP with XO.

\begin{tabular}{ccccc}
\hline Peptides & $\mathbf{T}(\mathbf{K})$ & $\mathbf{K}_{\mathbf{s v}}\left(\times \mathbf{1 0}^{\mathbf{4}} \mathbf{M}^{-\mathbf{1}}\right)$ & $\mathbf{K}_{\mathbf{q}}\left(\times \mathbf{1 0}^{\mathbf{1 2}} \mathbf{M}^{-\mathbf{1}} \mathbf{s}^{-\mathbf{1}}\right)$ & $\mathbf{R}^{\mathbf{2}}$ \\
\hline FPSV & 298 & 0.0542 & 0.0542 & 0.9898 \\
FPFP & 298 & 0.5608 & 0.5608 & 0.9999 \\
\hline
\end{tabular}

\subsection{Reversibility and the Type of Inhibition}

The reversibility and the type of $\mathrm{XO}$ inhibition by peptides were investigated to further evaluate the inhibitory reaction. The reversibility of FPSV (Figure 6A) and FPFP (Figure 6B) inhibition was assessed by evaluating the initial rate of the $\mathrm{XO}$ promoted reaction versus enzyme concentration at different inhibitor concentrations. A family of straight lines all passed through the origin. The slope of the line decreased with increasing inhibitor concentration, indicating that the inhibition of FPSV and FPFP on XO was reversible. This suggested that tetrapeptides could reversibly inhibit the $\mathrm{XO}$ activity rather than reducing the effective amount of the enzyme [31], and this implied that interaction between the peptide and $\mathrm{XO}$ is mainly a non-covalent intermolecular interaction [29].
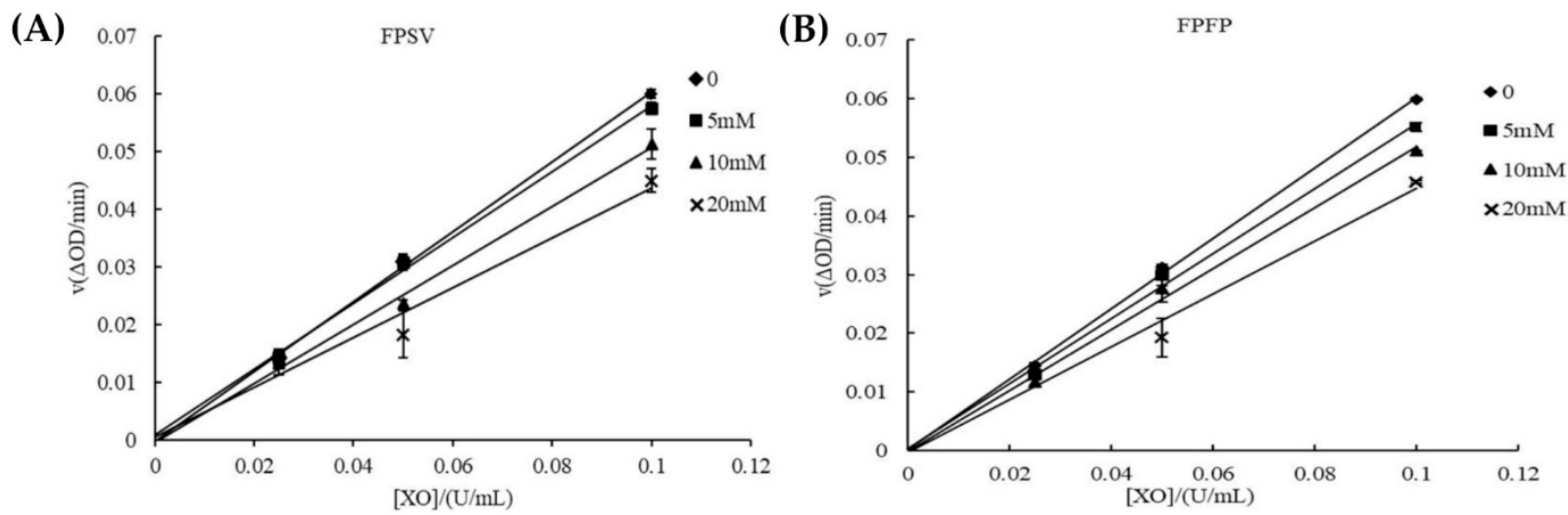

Figure 6. XO inhibition activity of FPSV (A) and FPFP (B) as a function of enzyme concentration at different inhibitor concentrations.

The XO inhibitory types of FPSV and FPFP were determined from Lineweaver-Burk double reciprocal plots. The initial rates at various concentrations of substrate (xanthine) with and without FPSV and FPFP were studied. The Lineweaver and Burk plots with and without FPSV and FPFP are illustrated in Figure 7A,B. The Lineweaver-Burk plots of $1 / \mathrm{v}$ versus $1 /$ [Xanthine] gave straight lines with different slopes but they intersected one another in the second quadrant, the $\mathrm{Km}$ (obtained from horizontal axis intercept values) increased and the $V \max$ (obtained from vertical axis intercept values) decreased, which indicated that FPSV and FPFP were mixed inhibitor [32]. Although this mechanism of inhibition remains to be determined, the finding of mixed-type inhibition of $\mathrm{XO}$ suggests that FPSV and FPFP may interact with the amino acid residue of XO domains distal to the substrate binding site, and then attenuate the activity of $\mathrm{XO}$ [33]. 

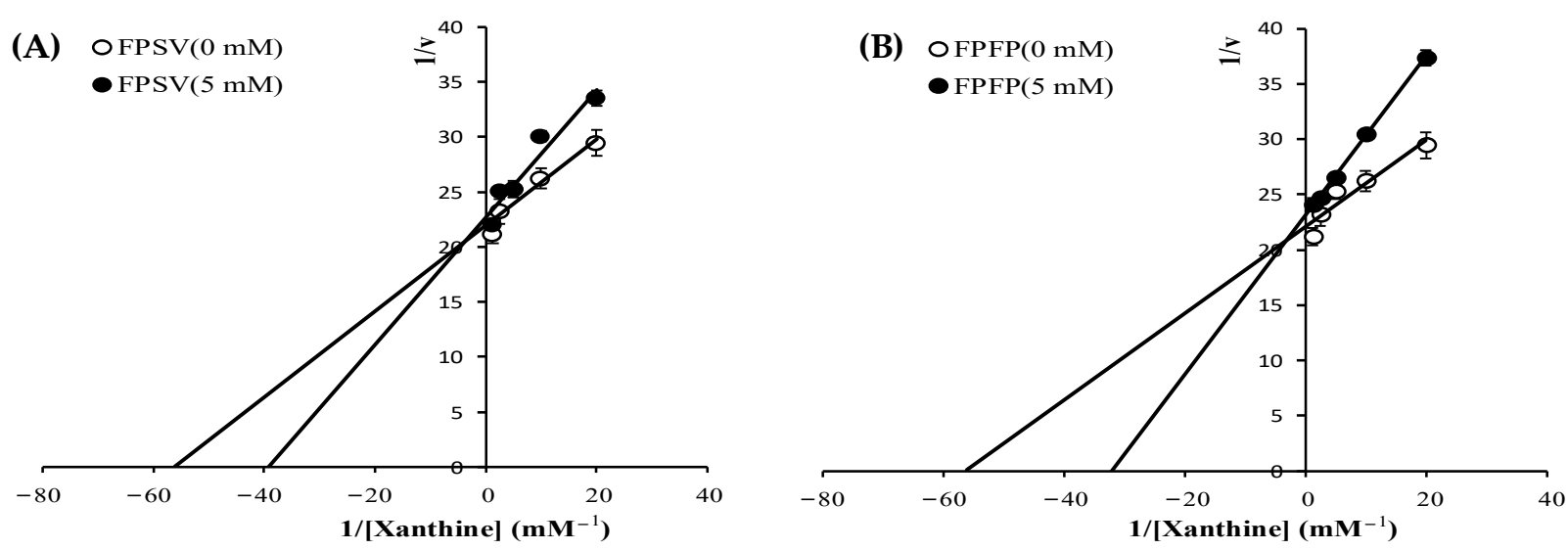

Figure 7. Lineweaver-Burk plots for XO inhibition activity with FPSV (A) and FPFP (B).

\subsection{Molecular Docking and Visual Analysis}

Molecular docking and visual analysis were used to predict and understand the interaction between the ligand (peptide) and biomacromolecule (e.g., XO). XO is a molybdenumcontaining enzyme that catalyzes the synthesis of uric acid. The molybdenum domain is the key active site in $\mathrm{XO}$, which is embraced by various amino acid residues (such as Phe ${ }^{649}, \mathrm{Phe}^{914}, \mathrm{Phe}^{1009}, \mathrm{Phe}^{1013}, \mathrm{Asn}^{768}, \mathrm{Lys}^{771}, \mathrm{Glu}^{802}, \mathrm{Leu}^{873}, \mathrm{Leu}^{648}, \mathrm{Ser}^{876}, \mathrm{Arg}^{880}$,

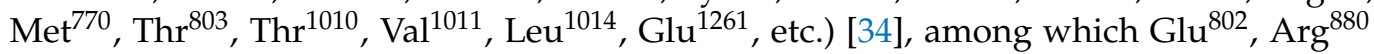
and $\mathrm{Glu}^{1261}$ are the key residues that activate the active domain and play a pivotal role in the catalytic reaction [35]. Furthermore, Phe ${ }^{914}$ residues located next to the surface of molybdenum active center also played an important role in the $\mathrm{XO}$ inhibitory activity [36].

As shown in Figure 8A, the Lys residue of tetrapeptide KGFP bounded with the Ala ${ }^{1079}$ $(2.47 \AA), \operatorname{Ser}^{1080}(2.65 \AA)$ and Glu ${ }^{802}(2.94 \AA)$ of XO by hydrogen bonds, and the Phe residue connect with Phe ${ }^{798}(4.24 \AA)$ of XO by $\pi-\pi$ stacking. The Phe residue of tetrapeptide FPSV had $\pi-\pi$ stacking with $\mathrm{Phe}^{914}\left(4.11 \AA\right.$ ) and $\mathrm{Phe}^{1009}$ (4.74 $\AA$ ) of XO (Figure 8B). Additionally, the Phe residues in the tetrapeptide FPFP were involved in the $\pi-\pi$ stacking with Phe ${ }^{914}$ (4.29 $\AA$ ), $\mathrm{Phe}^{1009}\left(4.89 \AA\right.$ ) and $\mathrm{Phe}^{775}(4.97 \AA$ ) of XO (Figure $8 \mathrm{C})$. Meanwhile, the Trp residue of pentapeptide WPDGR was found to have $\pi-\pi$ stacking with Phe $^{914}$ (3.91 $\AA, 4.40 \AA$ ), and Phe $^{1009}(4.83 \AA, 4.95 \AA$ ) of $X O$ (Figure 8D). Although all four peptides interact with the pivotal amino acid residues of $\mathrm{XO}$, they had different inhibitory effects on $\mathrm{XO}$. He et al. (2019) found that the XO inhibitory activity was closely associated with the Phe residue on peptides [13]. Besides, it was reported that a bioactive flavonoid from Spilanthes calva D.C. exhibiting the potent $X O$ inhibitory activity could be attributed to the formation of $\pi-\pi$ stacking between the inhibitor (flavonoid) and Phe ${ }^{914}$ of XO [37]. The Phe residue contained in the peptides (FPSV and FPFP) with potent XO inhibitory activity was found to have $\pi-\pi$ stacking with $\mathrm{Phe}^{914}$ in the XO. The XO inhibitory activity of the WPDGR was lower than that of the FPSV and FPFP, which might be attributed to the absence of Phe residue and the formation of $\pi-\pi$ stacking between Trp (but not Phe) residue and Phe ${ }^{914}$ in the XO. For the KGFP, it contained Phe residue but this residue did not interact with the pivotal amino acid residue ( $\mathrm{Phe}^{914}$ ) of $\mathrm{XO}$, which could result in the lower inhibitory effect on XO. The molecular docking results suggested that the $\pi-\pi$ stacking between the Phe residue in the peptide and $\mathrm{Phe}^{914}$ in the $\mathrm{XO}$ was apparently the key influencing factor that accounted for the different inhibitory effects of the four peptides. 


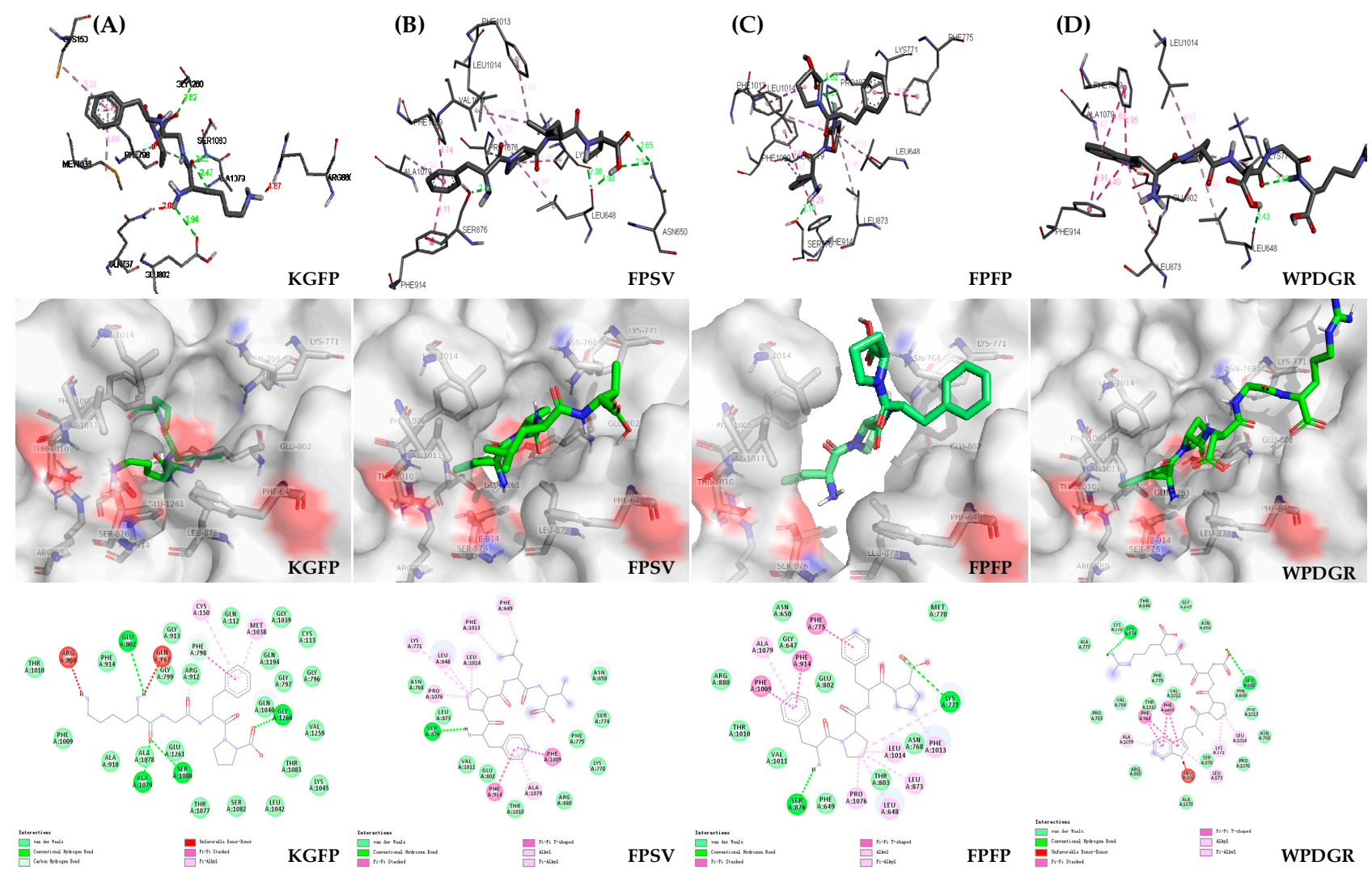

Figure 8. Molecular docking results of KGFP (A), FPSV (B), FPFP (C) and WPDGR (D).

\section{Materials and Methods}

\subsection{Materials}

Round scad was purchased from the Vanguard Supermarket (Guangzhou, China). Neutrase, protamex and alcalase were purchased from Cool Chemical Technology Co., Ltd. (Beijing, China). Cytochrome C (12,400 Da), aprotinin (6511.44 Da), bacitracin (1422.69 Da), L-glutathione oxidized (612.63 Da) and glutathione reduced (307.32 Da) were obtained from Macklin Biochemical Technology Co., Ltd. (Beijing, China). Xanthine, xanthine oxidase and chromatographic grade acetonitrile were purchased from Sigma Chemical Co. (St. Louis, MO, USA). All other chemicals and reagents were of analytical grade and purchased from Beiluo Biological Technology Co., Ltd. (Beijing, China).

\subsection{Preparation of Round Scad Hydrolysates (RSHs)}

RSHs were prepared based on the method of Jiang et al. (2014) [21] with slight modifications. The round scad meat $(100 \mathrm{~g})$ was minced and then mixed with distilled water $(200 \mathrm{~mL})$. The mixtures were hydrolyzed by three proteases at their respective optimum

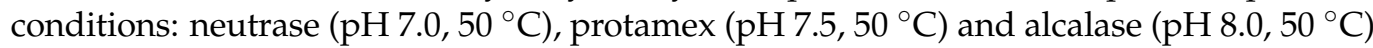
respectively, in an enzyme to substrate ratio of $0.3 \%(w / w)$ with a reaction time of $2-6 \mathrm{~h}$. Afterwards, the enzyme reaction was terminated by heating the solution in boiling water for $15 \mathrm{~min}$ and then centrifuged at $8000 \times g$ for $20 \mathrm{~min}$ at $4{ }^{\circ} \mathrm{C}$. The resulting supernatants were collected and freeze-dried to obtain RSHs and stored at $-20^{\circ} \mathrm{C}$ until use.

\subsection{XO Inhibitory Activity Assay}

The XO inhibitory activity assay was determined following the method of Masuoka et al. (2015) [38] with some modification. The XO inhibitory activity was measured by quantifying the rate of uric acid produced in the enzyme-catalyzed reaction. All samples were dissolved in $20 \mathrm{mM}$ sodium carbonate buffer at $\mathrm{pH} 7.5$. Briefly, $50 \mu \mathrm{L}$ of a test sample solution $(15 \mathrm{mg} / \mathrm{mL})$ or buffer solution for the blank, and $50 \mu \mathrm{L}$ of XO solution $(0.05 \mathrm{U} / \mathrm{mL})$ 
were added to the 96-well enzyme linked immunosorbent assay plate for pre-incubation at $37^{\circ} \mathrm{C}$ for $30 \mathrm{~min}$. Subsequently, the enzyme reaction was started by the addition of $150 \mu \mathrm{L}$ of xanthine solution $(0.42 \mathrm{mM})$. During the reaction, the dynamic changes of the absorbance of the sample were continuously recorded at $290 \mathrm{~nm}$. Each sample was tested three times. The XO inhibitory activity was calculated using the following formula:

$$
\text { Inhibition }(\%)=\left(\mathrm{V}_{1}-\mathrm{V}_{2}\right) / \mathrm{V}_{1} \times 100 \%
$$

where $V_{1}$ is the initial enzymatic reaction rate of the blank group, $V_{2}$ is the initial enzymatic reaction rate of sample group.

\subsection{Determination of the Degree of Hydrolysis}

Degree of hydrolysis was measured according to the method of Wu et al. (2019) [39] with some modifications. Kjeldahl method was used to determine total nitrogen (TPN), and potentiometric titration was used to determine the content of amino nitrogen (AN). Enzymatic hydrolysate $(5 \mathrm{~mL})$ was added to $100 \mathrm{~mL}$ deionized water and was titrated with $0.1 \mathrm{M} \mathrm{NaOH}$ to a $\mathrm{pH}$ value of 8.2. Then, an additional $5 \mathrm{~mL}$ of formaldehyde aqueous solution and was fully mixed and titrated with $0.1 \mathrm{M} \mathrm{NaOH}$ to a $\mathrm{pH}$ value of 9.2. The volume $(\mathrm{mL})$ of $0.1 \mathrm{M} \mathrm{NaOH}$ consumed after adding formaldehyde was recorded as $\mathrm{V}_{1}$. Deionized water was used instead of the sample for blank experiment, and the volume (mL) of $0.1 \mathrm{M} \mathrm{NaOH}$ consumed was recorded as $\mathrm{V}_{0}$. The calculation formula of $\mathrm{AN}$ was as follows: $\mathrm{AN}(\mathrm{g} / \mathrm{mL})=\left(\mathrm{V}_{1}-\mathrm{V}_{0}\right) \times \mathrm{C} \times 0.014 / 5$, where $\mathrm{C}$ is the actual concentration of $\mathrm{NaOH}(\mathrm{M}), 0.014$ is the mass $(\mathrm{g})$ of nitrogen equivalent to $1 \mathrm{~mL}$ of $1 \mathrm{M} \mathrm{NaOH}$, and 5 is the volume $(\mathrm{mL})$ of sample. TPN was determined by Kjeldahl method.

$$
\text { Degree of hydrolysis }(\%)=\mathrm{AN} / \mathrm{TPN} \times 100 \%
$$

\subsection{Molecular Weight Distribution of RSHs}

The molecular weight (MW) distribution of RSHs was determined by using LC-20AD high-performance liquid chromatography (HPLC) system (Shimadzu Co., Tokyo, Japan) with a TSK-Gel G2000SWXL column $(300 \times 7.8 \mathrm{~mm}, 5 \mu \mathrm{m})$ according to the method of Zhang et al. (2021) [40] with slight modifications. RSHs (2 mg/mL) were prepared with ultrapure water. Mobile phase A and mobile phase B were acetonitrile with $0.1 \%(v / v)$ Trifluoroacetic acid (TFA) and ultrapure water with $0.1 \%(v / v)$ TFA in isocratic elution program $(20 \% \mathrm{~A}: 80 \% \mathrm{~B})$. The flow rate was set at $0.5 \mathrm{~mL} / \mathrm{min}$. The absorbance was measured at $214 \mathrm{~nm}$. The standard curves of molecular weight were obtained using five standards: cytochrome C (12,400 Da), Aprotinin (6511.44 Da), bacitracin (1422.69 Da), L-Glutathione oxidized (612.63 Da), and Glutathione reduced (307.32 Da). The log of the MW (Da) of the standards was plotted as the function of retention time to get the standard curve: $\log \mathrm{MW}=-0.2212 \mathrm{t}+6.8856\left(\mathrm{R}^{2}=0.9964\right)$.

\subsection{Purification of RSHs with Immobilized Metal Affinity Chromatography (IMAC)}

IMAC is a good purification technique for proteins and peptides that exhibits the advantages of high selectivity, high binding capacity and high recovery [25]. The RSHs were purified according to the method of Lv et al. (2009) [41] with some modifications. A column $(16 \mathrm{~mm} \times 30 \mathrm{~cm})$ was packed with IMAC-Sepharose TM6 Fast Flow (GE Healthcare, Waukesha, WI, USA) and charged with $\mathrm{Fe}^{2+}$ (5 bed volumes, $200 \mathrm{mM} \mathrm{FeCl}_{2} \cdot 4 \mathrm{H}_{2} \mathrm{O}$ ). RSHs $(20 \mathrm{mg} / \mathrm{mL})$ was filtered through filter membrane $(0.22 \mu \mathrm{m})$. The nonspecific bound iron was removed with milli-Q water (5 bed volumes), subsequently, $2 \mathrm{~mL}$ of the sample solution was loaded onto the column. RSHs were isolated through a two-step elution program. Peptides without affinity to immobilized iron in the column were eluted with distilled water. Then, the bound peptides were eluted using $20 \mathrm{mM}$ phosphate-buffered saline, pH 7.4 (containing $500 \mathrm{mM} \mathrm{NaCl}$ ), with a flow rate of $2 \mathrm{~mL} / \mathrm{min}$. The absorbance of eluates was monitored at $220 \mathrm{~nm}$ with UV detector. The elution fractions were collected 
at room temperature and lyophilized, then stored at $-20{ }^{\circ} \mathrm{C}$ for further $\mathrm{XO}$ inhibitory activity evaluation.

\subsection{Identification and Synthesis of Peptide}

The purified fraction F2 exhibited the strongest XO inhibitory activity was identified by nano-HPLC-MS/MS on a Q Exactive Plus mass spectrometry (Thermo Fisher Scientific, Waltham, MA, USA). A volume of $9 \mu \mathrm{L}$ of sample was loaded into a chromatographic analytical column (Acclaim PepMap C18, $75 \mu \mathrm{m} \times 15 \mathrm{~cm}$ ) at a flow rate of $300 \mathrm{~nL} / \mathrm{min}$. The elution conditions were as follows: mobile phase $\mathrm{A}(0.1 \%$ formic acid in water $)$; mobile phase $\mathrm{B}(0.1 \%$ formic acid in $\mathrm{ACN})$; column temperature $\left(40{ }^{\circ} \mathrm{C}\right)$; linear elution program (0-30 min, 8-30\% B). Mass spectra were recorded over an $\mathrm{m} / \mathrm{z}$ range of $100-3000$. The electrospray voltage was $2 \mathrm{kV}$. Tandem mass spectra were processed by PEAKS Studio version X+ (Bioinformatics Solutions Inc., Waterloo, ON, Canada).

The identified peptide was synthesized via the solid-phase peptide synthesis technique by GL Biochemistry Co., Ltd. (Shanghai, China) for the analysis of its XO inhibitory activity. The synthetic substances were performed through HPLC with a Sinochrom ODS-BP column $(250 \times 4.6 \mathrm{~mm}, 5 \mu \mathrm{m}$, Shimadzu Corp. Cat, Kyoto, Japan). Then, $5 \mu \mathrm{L}$ solution was injected to the column and eluted by the system at a flow rate of $1 \mathrm{~mL} / \mathrm{min}$. The solvent $\mathrm{A}$ and solvent B were $0.1 \%$ TFA in $100 \%$ acetonitrile and $0.1 \%$ TFA in $100 \%$ water, respectively. A gradient elution program was used as follows: 0-25 min, 26-51\% A; 25.1-30 min, 100\% A at a flow rate of $1 \mathrm{~mL} / \mathrm{min}$. A UV detector was used to record at $220 \mathrm{~nm}$. Lastly, these identified peptides were verified via mass analysis using electrospray ionization-MS (Shimadzu, Kyoto, Japan), and the purity of the synthetic peptides was over 97\%. The experimental conditions of the mass spectrometer were as follows: ion spray voltage, $4.5 \mathrm{kV}$; nebulizer gas flow, $1.5 \mathrm{~L} / \mathrm{min}$; detector voltage, $1.5 \mathrm{kV}$; de-solvent tube voltage, $-20 \mathrm{~V}$; de-solvent tube temperature, $250{ }^{\circ} \mathrm{C}$; block temperature, $200{ }^{\circ} \mathrm{C}$.

\subsection{Fluorescence Spectroscopy Assay}

Fluorescence spectra were measured on an F-7000 Spectrofluorimeter (Hitachi Ltd., Ibaraki, Japan) with a $1.0 \mathrm{~cm}$ quartz cell and a thermostatic bath. Briefly, $2 \mathrm{~mL} \mathrm{XO}$ $(0.05 \mathrm{U} / \mathrm{mL})$ was titrated by continuous addition of peptides solution (to final concentrations ranging from 0 to $20.0 \times 10^{-4} \mathrm{M}$ ). Then, the obtained mixture was properly mixed and equilibrated for $5 \mathrm{~min}$. The slit widths for excitation and emission were set to $2.5 \mathrm{~nm}$. The fluorescence emission spectra were then measured in the emission wavelength range from 300 to $500 \mathrm{~nm}$, under $280 \mathrm{~nm}$ excitation wavelengths. The following Stern-Volmer equation was used to analyze the fluorescence quenching [7]:

$$
F_{0} / F=1+K_{\mathrm{sv}}[\mathrm{C}]=1+K_{\mathrm{q}} \tau_{0}[\mathrm{C}]
$$

where $F_{0}$ and $F$ represent the steady-state fluorescence intensities in the absence and presence of quencher, respectively. $K_{\mathrm{sv}}$ is the Stern-Volmer quenching constant. [C] is the quencher concentration. $K_{\mathrm{q}}$ is the quenching rate constant of biomolecule. $K_{\mathrm{q}}=K_{\mathrm{sv}} / \tau_{0}$, $\tau_{0}$ is the average lifetime of biomolecule in the absence of quencher and its value is approximately $10^{-8} \mathrm{~s}$. $K_{\mathrm{sv}}$ used to be estimated by linear regression plot slope of $F_{0} / F$ versus [27].

\subsection{Determination of Reversibility and the Type of Inhibition}

The plots of $v\left(\Delta \mathrm{OD}_{290 \mathrm{~nm}} / \mathrm{min}\right)$ versus the $\mathrm{XO}(\mathrm{U} / \mathrm{mL})$ at different concentrations of the inhibitors (peptides) were constructed to determine the reversibility of inhibitory behavior on XO [29]. All samples were dissolved in $20 \mathrm{mM}$ sodium carbonate buffer ( $\mathrm{pH} 7.5)$. Inhibitor solution $(0,5,10$ and $20 \mathrm{mM}$ ) and $\mathrm{XO}$ solution (from 0 to $0.1 \mathrm{U} / \mathrm{mL}$ ) were mixed and incubated at $37^{\circ} \mathrm{C}$ for $30 \mathrm{~min}$, and the concentration of the substrate xanthine was kept constant at $0.4 \mathrm{mM}$. The absorbance at $290 \mathrm{~nm}$ was then determined. $v$ is the initial enzymatic reaction rate of the reaction, which was investigated using the same method for the XO inhibitory activity assay. 
The type of the inhibition of $\mathrm{XO}$ activity by the inhibitors (peptides) was investigated using Lineweaver and Burk kinetic analysis. It was performed via evaluating the initial rate of reaction in the presence and absence of inhibitors at different xanthine concentration. Briefly, the peptide $(0$ and $5 \mathrm{mM})$ and $\mathrm{XO}(0.05 \mathrm{U} / \mathrm{mL})$ were mixed and incubated in the buffer (20 mM sodium carbonate buffer, $\mathrm{pH} 7.5)$ for $30 \mathrm{~min}$ at $37^{\circ} \mathrm{C}$. Subsequently, different xanthine concentrations $(0,0.05,0.1,0.2$ and $0.4 \mathrm{mM})$ were successively added into the solutions. Then, the dynamic changes of the absorbance at $290 \mathrm{~nm}$ were recorded, and $v$ was calculated using the same method above. $K_{\mathrm{m}}$ and $V_{\max }$ values, as corresponding kinetic parameters, were obtained from the Lineweaver and Burk double reciprocal plots [31].

\subsection{Molecular Docking and Interaction Analysis}

In order to explore the inhibitory effect of peptides on $\mathrm{XO}$, molecular docking studies were used to explore the potential binding sites and binding affinities between $\mathrm{XO}$ and peptides. The molecular docking studies were operated by Discovery studio 2016. The 3D structures of peptides were generated using Chem 3D. The X-ray crystal structure of bovine XO complex with inhibitor TEI-6720 (PDB ID: 1N5X) was downloaded from the Protein Data Bank website (http:/ / www.pdb.org/pdb/home/home.do, accessed on 30 September 2020). The process was performed according to Li et al. (2019) [36]. In docking simulation, peptides were used as ligands while $\mathrm{XO}$ was used as a receptor. PyMOL 2.0.2 was used to manage all the $3 \mathrm{D}$ structure picture files of biomacromolecules (XO) and ligands (recognized peptides). All water molecules and other small molecules in XO crystal structure were excluded, and polar hydrogen atoms and Gasteiger charges were added. After setting the default parameters, the reverse docking simulation between $\mathrm{XO}$ and peptide was performed. The results of molecular docking were further analysed by Discovery studio 2016.

\subsection{Statistical Analysis}

Duncan's $t$-tests were performed using one-way analysis of variance (ANOVA) on the IBM SPSS statistics 25.0 software. Differences were considered statistically significant at $p<0.05$.

\section{Conclusions}

In the present study, four novel XO inhibitory peptides (KGFP, FPSV, FPFP and WPDGR) were purified and identified from round scad (Decapterus maruadsi) protein hydrolysates (6-h hydrolysis by neutrase). The XO inhibitory peptides, especially for FPSV and FPFP, displayed great potential for XO inhibitory activity. Fluorescence spectra assay demonstrated that the fluorescence quenching mechanism of $\mathrm{XO}$ by the inhibitors of both FPSV and FPFP was a static quenching procedure. According to the inhibition kinetics study, the inhibition of both FPSV and FPFP was reversible, and the type of inhibition by both FPSV and FPFP was a mixed one. Molecular docking results revealed that the $\pi-\pi$ stacking between Phe residue (contained in peptides) and Phe ${ }^{914}$ (contained in the XO structure) played an important role in the XO inhibitory activity of peptides. These results suggested that peptides obtained from marine fish (Decapterus maruadsi) exhibited $\mathrm{XO}$ inhibitory effect and could be used as potential natural XO inhibitors.

Author Contributions: Conceptualization, X.H., Y.Z. and X.Y.; Data curation, X.H., Y.Z., S.C. and Y.W.; Formal analysis, X.H., Y.Z., S.C. and Y.W.; Funding acquisition, L.L. and X.Y.; Investigation, X.H. and Y.Z.; Methodology, Y.Z., S.C. and Y.W.; Resources, L.L.; Supervision, S.Z. and X.Y.; Validation, X.H., Y.Z. and S.Z.; Writing-original draft, X.H. and Y.Z.; Writing-review and editing, S.Z. and X.Y. All authors have read and agreed to the published version of the manuscript.

Funding: This work was supported by the Key-Area Research and Development Program of Guangdong Province (2020B1111030004), the Guangdong Basic and Applied Basic Research Foundation (2019A1515011588), the China Agriculture Research System of MOF and MARA (CARS-47), Pearl River S\&T Nova Program of Guangzhou (201906010081), the Special Scientific Research Funds for Central Non-profit Institutes, Chinese Academy of Fishery Sciences (2020TD69), and the Cen- 
tral Public-interest Scientific Institution Basal Research Funds, South China Sea Fisheries Research Institute, CAFS (2021SD06).

Institutional Review Board Statement: Not applicable.

Informed Consent Statement: Not applicable.

Data Availability Statement: Data are contained within the article.

Conflicts of Interest: The authors declare no conflict of interest.

\section{References}

1. Liu, C.; Zhou, H.N.; Zhang, R.R.; Wang, X.K.; He, S.W.; Zhang, J.B.; Guo, X.; Wang, Q.; Sun, J.Y. Anti-hyperuricemic and nephroprotective effect of geniposide in chronic hyperuricemia mice. J. Funct. Foods 2019, 61, 103355. [CrossRef]

2. Prasad Sah, O.S.; Qing, Y.X. Associations Between Hyperuricemia and Chronic Kidney Disease: A Review. Nephrourol. Mon. 2015, 7, e27233. [CrossRef]

3. Falasca, G.F. Metabolic diseases: Gout. Clin. Dermatol. 2006, 24, 498-508. [CrossRef]

4. Wang, Y.J.; Zhang, G.W.; Pan, J.H.; Gong, D.M. Novel Insights into the Inhibitory Mechanism of Kaempferol on Xanthine Oxidase. J. Agric. Food Chem. 2015, 63, 526-534. [CrossRef] [PubMed]

5. Enroth, C.; Eger, B.T.; Okamoto, K.; Nishino, T.; Pai, E. Crystal structures of bovine milk xanthine dehydrogenase and xanthine oxidase: Structure based mechanism of conversion. Proc. Natl. Acad. Sci. USA 2000, 97, 10723-10728. [CrossRef]

6. Hadizadeh, M.; Keyhani, E.; Keyhani, J.; Khodadadi, C. Functional and structural alterations induced by copper in xanthine oxidase. Acta Bioch. Biophys. Sin. 2009, 41, 603-617. [CrossRef]

7. Wan, Y.; Zou, B.; Zeng, H.L.; Zhang, L.N.; Chen, M.; Fu, G.M. Inhibitory effect of verbascoside on xanthine oxidase activity. Int. J. Biol. Macromol. 2016, 93, 609-614. [CrossRef] [PubMed]

8. Young, J.L.; Boswell, R.B.; Nies, A.S. Severe allopurinol hypersensitivity: Association with thiazides and prior renal compromise. Arch. Intern. Med. 1974, 134, 553-558. [CrossRef] [PubMed]

9. Gaffo, A.L.; Saag, K.G. Febuxostat: The evidence for its use in the treatment of hyperuricemia and gout. Core Evid. 2009, 4, 25-36.

10. Nongonierma, A.B.; Fitzgerald, R.J. Tryptophan-containing milk protein-derived dipeptides inhibit xanthine oxidase. Peptides 2012, 37, 263-272. [CrossRef]

11. Li, Q.Y.; Kang, X.Y.; Shi, C.C.; Li, Y.J.; Majumder, K.; Ning, Z.X.; Ren, J.Y. Moderation of hyperuricemia in rats via consuming walnut protein hydrolysate diet and identification of new antihyperuricemic peptides. Food Funct. 2018, 9, 107-116. [CrossRef]

12. Li, Y.J.; Kang, X.Y.; Li, Q.Y.; Shi, C.C.; Lian, Y.Y.; Yuan, E.D.; Zhou, M.; Ren, J.Y. Anti-hyperuricemic peptides derived from bonito hydrolysates based on in vivo hyperuricemic model and in vitro xanthine oxidase inhibitory activity. Peptides 2018, 107, 45-53. [CrossRef] [PubMed]

13. He, W.W.; Su, G.W.; Sun-Waterhouse, D.X.; Waterhouse, G.I.N.; Zhao, M.M.; Liu, Y. In vivo anti-hyperuricemic and xanthine oxidase inhibitory properties of tuna protein hydrolysates and its isolated fractions. Food Chem. 2019, 272, 453-461. [CrossRef] [PubMed]

14. Su, G.W.; He, W.W.; Zhao, M.M.; Waterhouse, G.I.N.; Sun-Waterhouse, D.X. Effect of different buffer systems on the xanthine oxidase inhibitory activity of tuna (Katsuwonus pelamis) protein hydrolysate. Food Res. Int. 2018, 105, 556-562. [CrossRef]

15. Murota, I.; Tamai, T.; Baba, T.; Sato, R.; Hashimoto, K.; Park, E.Y.; Nakamura, Y.; Sato, K. Uric acid lowering effect by ingestion of proteolytic digest of shark cartilage and its basic fraction. J. Food Biochem. 2010, 34, 182-194. [CrossRef]

16. Murota, I.; Tamai, T.; Baba, T.; Sato, N.; Park, E.Y.; Nakamura, Y.; Sato, K. Moderation of oxonate-induced hyperuricemia in rats via the ingestion of an ethanol-soluble fraction of a shark cartilage proteolytic digest. J. Funct. Foods 2012, 4, 459-464. [CrossRef]

17. Murota, I.; Taguchi, S.; Sato, N.; Park, E.Y.; Nakamura, Y.; Sato, K. Identification of antihyperuricemic peptides in the proteolytic digest of shark cartilage water extract using in vivo activity-guided fractionation. J. Agric. Food Chem. 2014, 62, $2392-2397$. [CrossRef]

18. Zhao, H.; Feng, Y.T.; Dong, C.M.; Li, Z.L. Spatiotemporal distribution of Decapterus maruadsi in spring and autumn in response to environmental variation in the northern South China Sea. Reg. Stud. Mar. Sci. 2021, 45, 101811. [CrossRef]

19. Thiansilakul, Y.; Benjakul, S.; Shahidi, F. Compositions, functional properties and antioxidative activity of protein hydrolysates prepared from round scad (Decapterus maruadsi). Food Chem. 2007, 103, 1385-1394. [CrossRef]

20. Chen, H.H.; Wang, S.; Zhou, A.; Miao, J.Y.; Liu, J.Y.; Benjakul, S. A novel antioxidant peptide purified from defatted round scad (Decapterus maruadsi) protein hydrolysate extends lifespan in Caenorhabditis elegans. J. Funct. Foods 2020, 68, 103907. [CrossRef]

21. Jiang, H.P.; Tong, T.Z.; Sun, J.H.; Xu, Y.J.; Zhao, Z.X.; Liao, D.K. Purification and characterization of antioxidative peptides from round scad (Decapterus maruadsi) muscle protein hydrolysate. Food Chem. 2014, 154, 158-163. [CrossRef] [PubMed]

22. Zhang, Q.; Su, G.W.; Zhao, T.T.; Wang, S.G.; Sun, B.G.; Zheng, L.; Zhao, M.M. The memory improving effects of round scad (Decapterus maruadsi) hydrolysates on sleep deprivation-induced memory deficits in rats via antioxidant and neurotrophic pathways. Food Funct. 2019, 10, 7733-7744. [CrossRef] [PubMed]

23. Hu, X.; Yang, X.Q.; Wang, T.T.; Li, L.H.; Wu, Y.Y.; Zhou, Y.; You, L.J. Purification and identification of antioxidant peptides from round scad (Decapterus maruadsi) hydrolysates by consecutive chromatography and electrospray ionization-mass spectrometry. Food Chem. Toxicol. 2019, 135, 110882. [CrossRef] 
24. Craik, D.J.; Fairlie, D.P.; Liras, S.; Price, D. The future of peptide-based drugs. Chem. Biol. Drug Des. 2013, 81, 136-147. [CrossRef] [PubMed]

25. Guo, L.D.; Harnedy, P.A.; Li, B.F.; Hou, H.; Zhang, Z.H.; Zhao, X.; FitzGerald, R.J. Food protein-derived chelating peptides: Biofunctional ingredients for dietary mineral bioavailability enhancement. Trends Food Sci. Technol. 2014, 37, 92-105. [CrossRef]

26. Liu, P.R.; Lan, X.D.; Yaseed, M.; Chai, K.G.; Zhou, L.Q.; Sun, J.H.; Lan, P.; Tong, Z.F.; Liao, D.K. Immobilized metal affinity chromatography matrix modified by poly (ethylene glycol) methyl ether for purification of angiotensin I-converting enzyme inhibitory peptide from casein hydrolysate. J. Chromatogr. B 2020, 1143, 122042. [CrossRef]

27. Peng, W.; Ding, F.; Jiang, Y.T.; Sun, Y.; Peng, Y.K. Evaluation of the biointeraction of colorant flavazin with human serum albumin: Insights from multiple spectroscopic studies, in silico docking and molecular dynamics simulation. Food Funct. 2014, 5, $1203-1217$. [CrossRef] [PubMed]

28. Nongonierma, A.B.; Mooney, C.; Shields, D.C.; Fitzgerald, R.J. Inhibition of dipeptidyl peptidase IV and xanthine oxidase by amino acids and dipeptides. Food Chem. 2013, 141, 644-653. [CrossRef]

29. Zeng, N.; Zhang, G.W.; Hu, X.; Pan, J.H.; Gong, D.M. Mechanism of fisetin suppressing superoxide anion and xanthine oxidase activity. J. Funct. Foods 2019, 58, 1-10. [CrossRef]

30. Yang, J.; Chang, R.R.; Ge, S.J.; Zhao, M.; Liang, C.F.; Xiong, L.; Sun, Q.J. The inhibition effect of starch nanoparticles on tyrosinase activity and its mechanism. Food Funct. 2016, 7, 4804-4815. [CrossRef]

31. Zeng, N.; Zhang, G.W.; Hu, X.; Pan, J.H.; Zhou, Z.S.; Gong, D.M. Inhibition mechanism of baicalein and baicalin on xanthine oxidase and their synergistic effect with allopurinol. J. Funct. Foods 2018, 50, 172-182. [CrossRef]

32. Tavani, C.; Bianchi, L.; Palma, A.D.; Passeri, G.I.; Punzi, G.; Pierri, C.L.; Lovece, A.; Cavalluzzi, M.M.; Franchini, C.; Lentini, G.; et al. Nitro-substituted tetrahydroindolizines and homologs: Design, kinetics, and mechanism of $\alpha$-glucosidase inhibition. Bioorg. Med. Chem. Lett. 2017, 27, 3980-3986. [CrossRef]

33. Wang, Z.Q.; Kwon, S.H.; Hwang, S.H.; Kang, Y.H.; Lee, J.Y.; Lim, S.S. Competitive binding experiments can reduce the false positive results of affinity-based ultrafiltration-HPLC: A case study for identification of potent xanthine oxidase inhibitors from Perilla frutescens extract. J. Chromatogr. B 2017, 1048, 30-37. [CrossRef]

34. Nishino, T.; Okamoto, K.; Eger, B.T.; Pai, E.F.; Nishino, T. Mammalian xanthine oxidoreductase-mechanism of transition from xanthine dehydrogenase to xanthine oxidase. FEBS J. 2008, 275, 3278-3289. [CrossRef]

35. Okamoto, K.; Kusano, T.; Nishino, T. Chemical nature and reaction mechanisms of the molybdenum cofactor of xanthine oxidoreductase. Curr. Pharm. Des. 2013, 19, 2606-2614. [CrossRef]

36. Li, Q.Y.; Shi, C.C.; Wang, M.; Zhou, M.; Liang, M.; Zhang, T.; Yuan, E.D.; Wang, Z.; Yao, M.J.; Ren, J.Y. Tryptophan residue enhances in vitro walnut protein-derived peptides exerting xanthine oxidase inhibition and antioxidant activities. J. Funct. Foods 2019, 53, 276-285. [CrossRef]

37. Jayaraj, P.; Mathew, B.; Parimaladevi, B.; Ramani, V.A.; Govindarajan, R. Isolation of a bioactive flavonoid from Spilanthes calva D.C. in vitro xanthine oxidase assay and in silico study. Biomed. Prev. Nutr. 2014, 4, 481-484. [CrossRef]

38. Masuoka, N.; Nihei, K.I.; Maeta, A.; Yamagiwa, Y.; Kubo, I. Inhibitory effects of cardols and related compounds on superoxide anion generation by xanthine oxidase. Food Chem. 2015, 166, 270-274. [CrossRef] [PubMed]

39. Wu, W.M.; He, L.C.; Liang, Y.H.; Yue, L.L.; Peng, W.M.; Jin, G.F.; Ma, M.H. Preparation process optimization of pig bone collagen peptide-calcium chelate using response surface methodology and its structural characterization and stability analysis. Food Chem. 2019, 284, 80-89. [CrossRef] [PubMed]

40. Zhang, J.; Li, M.; Zhang, G.N.; Tian, Y.; Kong, F.B.; Xiong, S.; Zhao, S.B.; Jia, D.; Manyande, A.; Du, H.Y. Identification of novel antioxidant peptides from snakehead (Channa argus) soup generated during gastrointestinal digestion and insights into the anti-oxidation mechanisms. Food Chem. 2021, 337, 12791. [CrossRef]

41. Lv, Y.; Liu, Q.; Bao, X.L.; Tang, W.X.; Yang, B.C.; Guo, S.T. Identification and characteristics of iron-chelating peptides from soybean protein hydrolysates using IMAC-Fe ${ }^{3+}$. J. Agric. Food Chem. 2009, 57, 4593-4597. [CrossRef] [PubMed] 